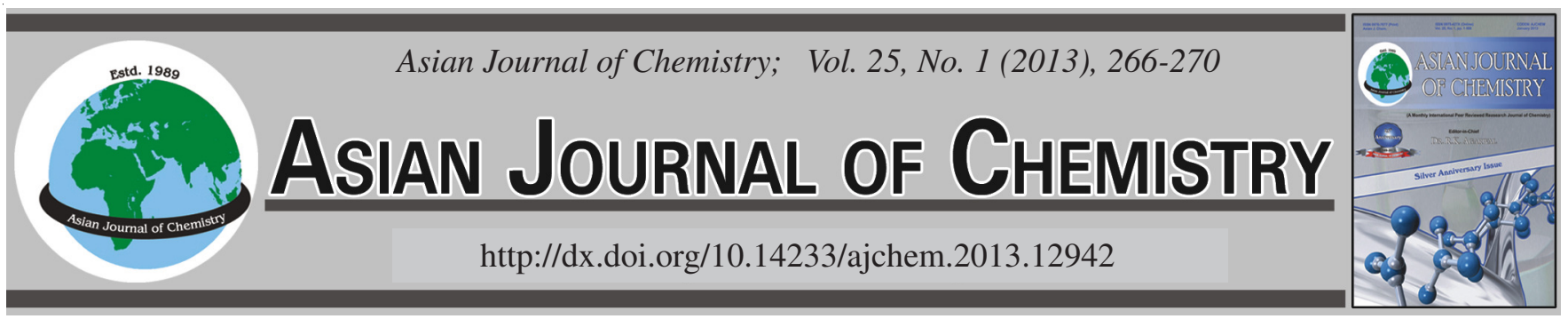

\title{
Recycling of Red Mud as a Building Material via a Stabilization/Solidification Method
}

\author{
Aylin YildiZ, Aylin Akyildiz and EsRa TinMaz KöSE*
}

Çorlu Engineering Faculty, Namik Kemal University, 59860 Çorlu, Tekirdag, Turkey

*Corresponding author: E-mail: mustay22@gmail.com; aylinfirinci@hotmail.com; ayildiz@nku.edu.tr

This study examines stabilization/solidification techniques for red mud/cement systems that involve the production of construction products while minimizing contamination and recycling the red mud. In these techniques, the polluted components of red mud are fixed in a cement body via adsorption and confinement mechanisms and thus, the possible impact of these pollutants on the environment is minimized. In the first step of this study, the physical, chemical, radioactive and mineralogical properties of the material used were determined. Second, red mud was used to replace portland cement in the following proportions: $0,5,10,15,20,25,30,40$ and $50 \%$ of portland cement by weight. Finally, the usability of red mud as a construction product and the environmental effects of such usage were determined.

Key Words: Red mud, Concrete, Recycling, Stabilization/solidification.

\section{INTRODUCTION}

The use of solid wastes in the building industry can contribute to achieve the sustainable development of certain industrial activities, while it might help to reduce production costs. Selected wastes may be considered alternative/secondary raw materials, gaining an intrinsic value in the market while costs for disposal are eliminated ${ }^{1}$.

Stabilization/solidification $(\mathrm{S} / \mathrm{S})$ technologies are expected to increase in treating hazardous wastes prior to land disposal ${ }^{2-4}$. Cement based stabilization/solidification processes are particularly appropriate for heavy metal-contaminated wastes, sludge and soils $\mathrm{s}^{5-7}$. Solidification/stabilization is a process that involves the mixing of a waste with a binder to reduce the contaminant leachability by both physical and chemical means and to convert the hazardous waste into an environmentally acceptable waste form for land disposal or construction use ${ }^{8}$. Solidification/stabilization method for red mud, both the beneficial use of red mud will be evaluated and the environmental impacts will be minimized since the contaminators within will be fixed in solidified form.

Red mud is a solid waste derived from bauxite refining processes, chiefly the Bayer process. Its disposal poses a significant environmental problem due to its high alkalinity and fine particle size ${ }^{9}$. Through this process, bauxite is digested in a concentrated caustic soda $(\mathrm{NaOH})$ solution at high pressure and elevated temperatures $\left(270{ }^{\circ} \mathrm{C}\right)$, in order to obtain the alumina trihydrate $\left(\mathrm{Al}_{2} \mathrm{O}_{3} \cdot 3 \mathrm{H}_{2} \mathrm{O}\right)^{10,11}$. This process leads to the formation of insoluble hydroxides where the impurities are concentrated, after proper washing, settling and filtration operations. Such is the case of the red mud, containing goethite $(\alpha-\mathrm{FeOOH})$, hematite $\left(\alpha-\mathrm{Fe}_{2} \mathrm{O}_{3}\right)$, bohemite $(\gamma \mathrm{AlO}(\mathrm{OH}))$, quartz $\left(\mathrm{SiO}_{2}\right)$, sodalite $\left(\mathrm{Na}_{4} \mathrm{Al}_{3} \mathrm{SiO}_{12} \mathrm{Cl}\right)$ and gypsum $\left(\mathrm{CaSO}_{4} \cdot 2 \mathrm{H}_{2} \mathrm{O}\right)$ as major phases and calcite $\left(\mathrm{CaCO}_{3}\right)$, whewellite $\left(\mathrm{CaC}_{2} \mathrm{O}_{4} \cdot \mathrm{H}_{2} \mathrm{O}\right)$, gibbsite $\left[\mathrm{Al}(\mathrm{OH})_{3}\right]$ and $\mathrm{TiO}_{2}$ as minor components ${ }^{10}$. Obviously, the exact composition of the mud depends on the origin of bauxite and also on processing details. Physically, the red mud particles are fine $(<10 \mu \mathrm{m})$ and then show high surface area $\left(13-22 \mathrm{~m}^{2} / \mathrm{g}\right)$. Due to its composition, it generates highly alkaline ( $\mathrm{pH} 10-12.5)$ slurries when mixed with water, since it releases $\mathrm{OH}^{-}$ions ${ }^{2,10,12}$. This characteristic contributes to the hazardous classification of such waste ${ }^{13}$.

In general, the production of 1 ton alumina generates 1-2 ton(dry weight) of red mud. Thus, the storage of these massive amounts is economically and environmentally problematic, due to the risk of contamination of natural resources and living organisms ${ }^{14,15}$. In this way, efforts have been made to develop suitable treating methods, such as drying and neutralization. The correct storage and containment was also optimized $^{16}$ while distinct reuse ways are under evaluation. These include applications in the agriculture or in the treatment of wastewater, as additive to plastic or ceramic materials (bricks, tiles) $)^{14,17,18}$. Cement based materials are obvious attractive solutions, since production rates are also massive. Red mud has been tested in the production of special Portland clinkers $^{19-22}$, as source of iron oxide and alumina, or additive of mortars or concretes ${ }^{12,23-25}$ acting as pigment (due to the high concentration of iron and titanium oxides) or as pozzolan. 
TABLE-2

CHEMICAL COMPOSITIONS OF THE RED MUD (DATA OBTAINED FROM THE XRD ANALYSIS)

\begin{tabular}{lcccccccccc}
\hline Oxide & $\mathrm{SiO}_{2}$ & $\mathrm{Al}_{2} \mathrm{O}_{3}$ & $\mathrm{Fe}_{2} \mathrm{O}_{3}$ & $\mathrm{CaO}$ & $\mathrm{MgO}$ & $\mathrm{SO}_{3}$ & $\mathrm{Na}_{2} \mathrm{O}$ & $\mathrm{K}_{2} \mathrm{O}$ & $\mathrm{TiO}_{2}$ & $\mathrm{P}_{2} \mathrm{O}_{5}$ \\
\hline Red mud (wt \%) & 13.254 & 21.995 & 36.422 & 4.452 & 0.293 & 5.486 & 12.532 & 0.520 & 4.497 & 0.021 \\
\hline
\end{tabular}

However, the high alkalinity or the presence of vestiges of caustic soda $^{26}$ and the radiological aspects ${ }^{27}$ may limit the amount to be added.

The aim of this study is to determine the usability of red mud as a construction product and to research the environmental effects of such a usage. For this purpose, eight series of concrete specimens were prepared using Portland cement and a varying amount of ash $(0 \%$ to $50 \%)$ to study the stabilization of red mud by solidification.

\section{EXPERIMENTAL}

Red mud: Experiments were done using red mud resulting from the combustion of coal for home heating in the town of Çorlu in the Tekirdag Province of Turkey. Table- 1 shows the physical properties of the red mud. The chemical compositions, metal content, radioactivity levels and specific surface area of the red mud were determined using an X-ray fluorescence spectrometer and X-ray diffraction spectroscopy (XRD), conductivity measurements (WTW Cond. 330i Set) and a surface area analysis (quantachrome instruments, Nova 400E model), respectively. The major elements analyzed in red mud are detailed in Table- 2 . The heavy metal content and the radioactivity analysis of the red mud are shown in Tables 3 and 4, respectively.

\begin{tabular}{lcc}
\multicolumn{3}{c}{ TABLE-1 } \\
\multicolumn{2}{c}{ PHYSICAL PROPERTIES OF THE RED MUD } \\
\hline Parameter & & Value \\
\hline Colour & $\mathrm{kg} / \mathrm{m}^{3}$ & Red \\
Density & $\mathrm{cc} / \mathrm{g}$ & 0.019 \\
Pore volume & $\mathrm{m}^{2} / \mathrm{g}$ & 13.765 \\
Specific surface area & $\mathrm{dS} / \mathrm{m}$ & 10.58 \\
Electrical conductivity & & 8.60 \\
$\mathrm{pH}$ & & \\
\hline
\end{tabular}

TABLE-3

\begin{tabular}{lcccc}
\multicolumn{5}{c}{ TABLE-3 } \\
METAL CONTENT IN THE RED MUD \\
\hline Element & As & Zn & $\mathrm{Cr}$ & $\mathrm{Ni}$ \\
\hline Red mud (wt \%) & 0.020 & 0.000 & 0.074 & 0.043 \\
\hline
\end{tabular}

\begin{tabular}{|c|c|c|c|c|c|}
\hline \multicolumn{6}{|c|}{$\begin{array}{r}\text { TABLE-4 } \\
\text { RADIOACTIVITY ANALYSIS }\end{array}$} \\
\hline Element & Cs-134 & Cs-137 & K-40 & Ra-226 & Th-232 \\
\hline $\begin{array}{c}\text { Red mud } \\
(\mathrm{Bq} / \mathrm{kg})\end{array}$ & $<4.4$ & $<5.7$ & $\begin{array}{c}110.4 \pm \\
22.4\end{array}$ & $\begin{array}{c}128.1 \pm \\
3.2\end{array}$ & $\begin{aligned} 357.4 \pm \\
9.6\end{aligned}$ \\
\hline
\end{tabular}

The mineralogical analysis of the ash specimen was carried out using a $\mathrm{Cu} \mathrm{X}$-ray tube (1.5405 Angstroms) and quartz, hematite, calcite, feldspar and magnesioferrite were observed in the compound. The XRD pattern is given in Fig. 1, SEM micrograph of the red mud is given Fig. 2 and a plot of the surface area of the red mud is given in Fig. 3.

Characterization of the other materials: Cement (CEM I 42.5 R) was supplied from Akçansa, in Turkey. It complied with the requirement of European Standards EN 197-1. The physical, chemical and mechanical properties of the cement are given in Table 5 .

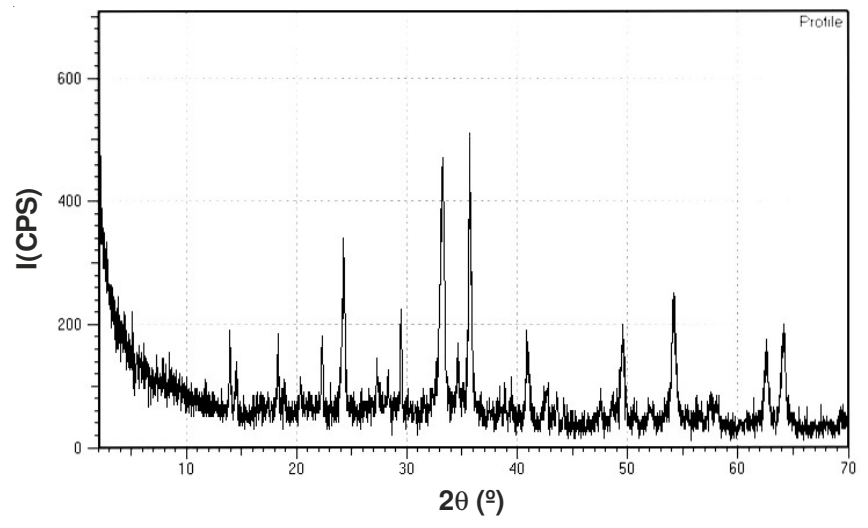

Fig. 1. XRD pattern of the red mud

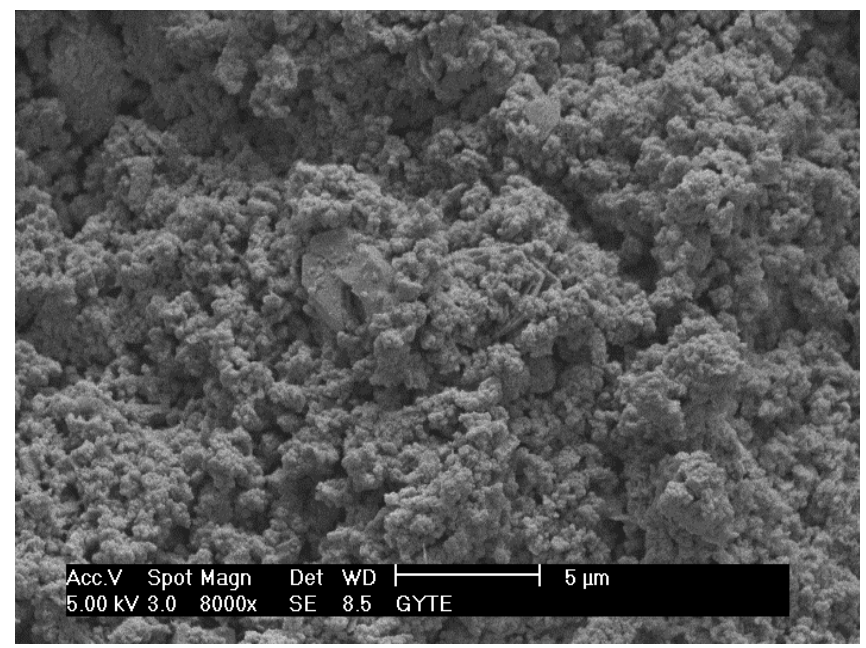

Fig. 2. SEM micrograph of the red mud

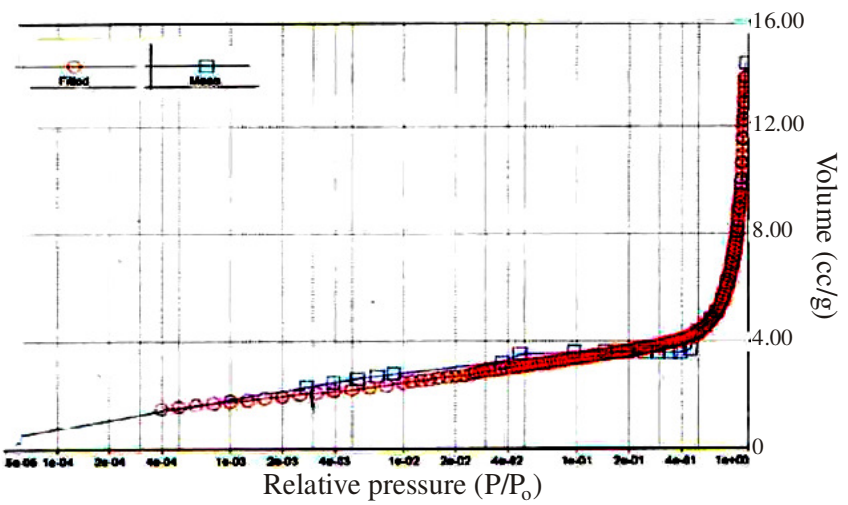

Fig. 3. Surface area of the red mud

A maximum $22 \mathrm{~mm}$ nominal size of the crushed aggregate was used. The coarse aggregates were calcareous stone: crushed stone I (6-12 mm), crushed stone II (12-22 mm), natural sand (0-3 mm) and crushed dusty stone dusty (0-6 mm). The granulometric curves and the mixture size distribution 
are provided in Fig. 4. The specific gravities of the raw materials are listed in Table-6.

\begin{tabular}{clcr}
\multicolumn{4}{c}{ TABLE-5 } \\
\multicolumn{4}{c}{ PHYSICAL, CHEMICAL AND MECHANICAL } \\
& PROPERTIES OF CEMENT & \\
\hline & Properties & Unit & Cement \\
\hline \multirow{3}{*}{ Chemical } & Insoluble residue & $\%$ & 0.2500 \\
properties & $\mathrm{SO}_{3}$ & $\%$ & 3.2200 \\
& Loss on ignition & $\%$ & 1.0000 \\
& $\mathrm{Cl}^{-}$ & $\%$ & 0.0445 \\
\hline \multirow{5}{*}{ Physical } & Specific gravity & $\mathrm{g} / \mathrm{cm}^{3}$ & 3.15 \\
& Initial setting time & $\mathrm{min}$ & 146 \\
& Final setting time & $\mathrm{min}$ & 193 \\
& Volume expansion & $\mathrm{mm}$ & 1 \\
& Specific surface area & $\mathrm{cm}^{2} / \mathrm{g}$ & 3710 \\
& Fineness 45 $\mu \mathrm{m}$ & $\%$ & 5.8 \\
& Fineness $90 \mu \mathrm{m}$ & $\%$ & 0.3 \\
\hline \multirow{3}{*}{$\begin{array}{c}\text { Mechanical } \\
\text { Properties }\end{array}$} & Compressive strength, 2 days & $\mathrm{MPa}$ & 28.9 \\
& Compressive strength, 7 days & $\mathrm{MPa}$ & 43.8 \\
& Compressive strength, 28 & $\mathrm{MPa}$ & \\
& days & & 58.3 \\
\hline & & &
\end{tabular}

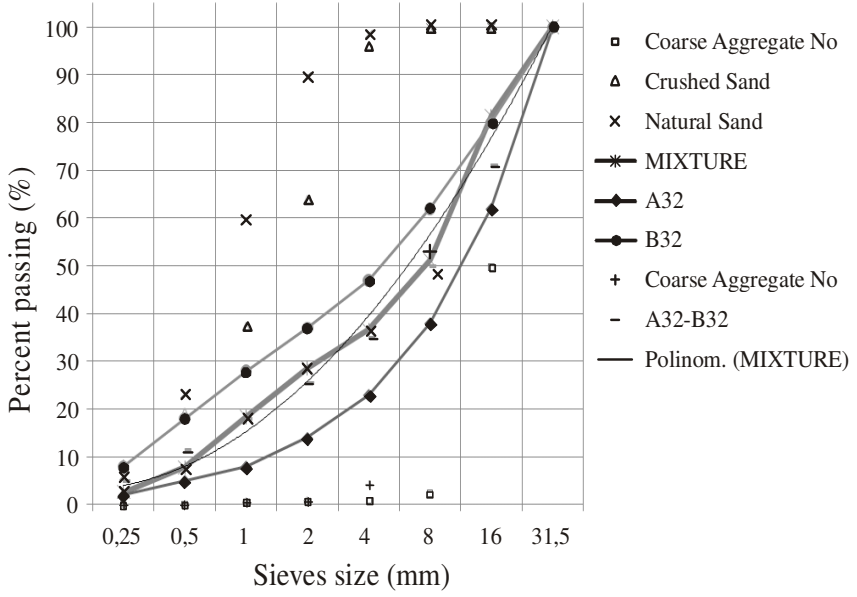

Fig. 4. Granulometric curves for the aggregates and mixtures

\begin{tabular}{cccccc}
\multicolumn{7}{c}{ TABLE-6 } \\
SPECIFIC GRAVITY OF THE RAW MATERIALS \\
\hline Material & $\begin{array}{c}\text { Portland } \\
\text { cement }\end{array}$ & $\begin{array}{c}\text { Crushed } \\
\text { stone I }\end{array}$ & $\begin{array}{c}\text { Crushed } \\
\text { stone II }\end{array}$ & $\begin{array}{c}\text { Natural } \\
\text { sand }\end{array}$ & $\begin{array}{c}\text { Crushed } \\
\text { dusty stone }\end{array}$ \\
\hline $\begin{array}{c}\text { Red mud } \\
\left(\mathrm{kg} / \mathrm{m}^{3}\right)\end{array}$ & 3.15 & 2.564 & 2.564 & 2.630 & 2.500 \\
\hline
\end{tabular}

Solidification method: The amount of cement used in the mixtures was $300 \mathrm{~kg} / \mathrm{m}^{3}$. The volume of the aggregate was used to determine the aggregate weight. Red mud was used to replace portland cement at $0,5,10,15,20,25,30,40$ and $50 \%$ by weight. Aggregate dry mixing was applied for approximately $30 \mathrm{~s}$. Next, cement and red mud were added at different rates, dry mixing was applied for another $30 \mathrm{~s}$, water was added to the mixture and the mixture was mixed for 1.5 min. After this period, the mixer was stopped and the mixture was left to rest for $1 \mathrm{~min}$. A slump test was performed on every concrete sample produced and the slump value was set to approximately $7-8 \mathrm{~cm}$ in all of the mixtures. The mixtures were cast into cubic molds $(150 \mathrm{~mm} \times 150 \mathrm{~mm} \times 150 \mathrm{~mm})$. The molds were then filled with concrete in three layers. Each layer was compacted using a vibrating table for $10 \mathrm{~s}$ and then stored in molds at room temperature for $24 \mathrm{~h}$. After that, the specimens were removed from the molds. The specimens were cured in air at room temperature $\left(\approx 23-25^{\circ} \mathrm{C}\right.$ and relative humidity $\approx 75 \%-85 \%$ ) for 7 and 28 days. After 7 and 28 days of curing, the samples were crushed and sieved to $9 \mathrm{~mm}$ and were extracted using leaching tests.

Compressive strength test: The compressive strength of the cubic specimens $(150 \times 150 \times 150 \mathrm{~mm})$ was measured according to TS EN 12390-3 (2002) at the ages of 7 and 28 days. Three specimens were tested for each mixture at each age and the mean values were reported.

Leaching test: The stabilization/solidification efficacy was assessed from a chemical point of view according to the leaching (U.S. EPA TCLP) test. The U.S. EPA TCLP (toxicity characteristic leaching procedure $)^{27}$ method no. 1311 test consists of stirring the granular material $(<9 \mathrm{~mm})$ with an acetic acid solution at $\mathrm{pH} 4.93 \pm 0.05$ (fluid no. 2) with a liquid/solid ratio (L/S) of 20 for $18 \mathrm{~h}$. After the test, samples were filtered through Whatman membrane filters (pore size $0.45 \mu \mathrm{m})$. When the procedures were completed, the metal contents in the solutions were determined using inductively coupled plasma techniques.

Water microorganism growth test: To study the effects of the produced concrete on water quality, a water microorganism growth test was done in accordance with BS 6920 (1996). For these measurements, the solidified material was left for 21 days in water whose dissolved oxygen content had been premeasured. According to the method, the difference in the amount of dissolved oxygen at the beginning and the end of the experiment was less than $2.4 \mathrm{mg} / \mathrm{L}$, which means that no microbiologic reproduction had occurred in the medium.

\section{RESULTS AND DISCUSSION}

Compressive strength: Three specimens of solidified/ stabilized cement and a pure cement sample (blank sample) (Table-4) were subjected to compressive strength testing after curing using a compression machine. The ends of the specimens were ground flat and parallel before testing and the results reported are the average of three specimens. Among the concrete samples in which red mud was used in place of cement $5,10,15,20,25,30,40$ and $50 \%$ (for which 7-day cure samples were obtained) the group that yielded the value closest to the blank sample was the $10 \%$ red mud group. For the 28 day cure samples, the closest value to the blank sample was obtained from the $5 \%$ mixture. As seen in Fig. 3, according to the 28-day cure results, the concrete samples that were produced with mixtures of up to $20 \%$ red mud satisfy the 30 MPa strength requirement prescribed for C25 class concrete. The 7 and 28 days strength values and their differentiation rates are given in Table- 7 and the compressive strength of the 7 and 28 days cure specimens is given Fig. 5.

As seen in Table-4 and Fig. 5, the inclusion of red mud reduced the strength of the concrete specimens. The loss of strength varied in a nearly linear manner as the percentage of red mud increased. When the curing time is taken into account, it can be observed that the strength increased with time. Notably, concrete specimens with compressive strength levels near $30 \mathrm{MPa}$ could be prepared; this characteristic indicates that concrete 
specimens produced with red mud replacing cement in amounts of up to $20 \%$ could be used as building materials.

\begin{tabular}{|c|c|c|c|c|}
\hline \multicolumn{5}{|c|}{$\begin{array}{c}\text { TABLE-7 } \\
7 \text { AND } 28 \text { DAYS COMPRESSIVE STRENGTH VALUES } \\
\text { OF RED MUD AND THE PERCENT CHANGE }\end{array}$} \\
\hline \multirow{2}{*}{$\begin{array}{l}\text { Red mud } \\
(\%)\end{array}$} & \multicolumn{2}{|c|}{ Compressive strength (MPa) } & \multicolumn{2}{|c|}{ Percent change } \\
\hline & 7 days & 28 days & 7 days & 28 days \\
\hline 0 & 32.12 & 37.98 & 100 & 100 \\
\hline 5 & 30.50 & 36.39 & 101 & 97 \\
\hline 10 & 28.35 & 37.34 & 101 & 84 \\
\hline 15 & 26.61 & 30.53 & 84 & 82 \\
\hline 20 & 26.26 & 32.11 & 87 & 88 \\
\hline 25 & 24.92 & 27.29 & 62 & 74 \\
\hline 30 & 25.70 & 24.25 & 64 & 78 \\
\hline 40 & 18.75 & 21.06 & 48 & 75 \\
\hline 50 & 18.96 & 20.20 & 32 & 53 \\
\hline
\end{tabular}

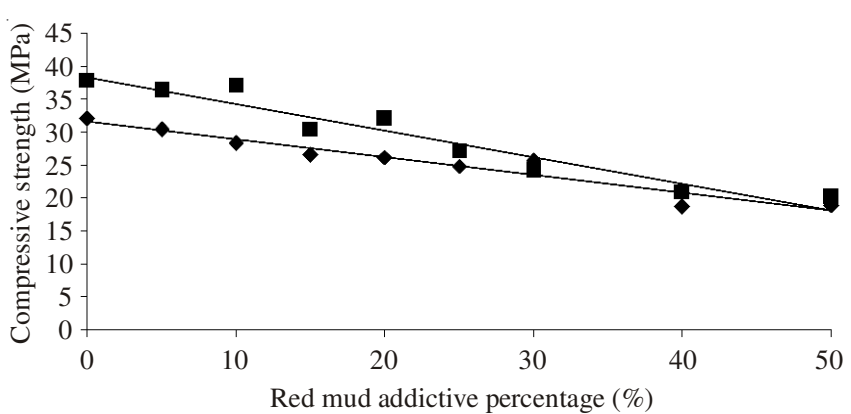

- 7 day compressive strength $\quad 28$ day compressive strength

Fig. 5. The compressive strength of the 7 and 28 days cure specimens

Leaching test: Table- 8 shows the results obtained from the leaching test. It can be seen that the values of the heavy metals measured for the concrete specimens were similar to those obtained from the red mud samples themselves and to the blank concrete samples for each replacement percentage. Generally, as the percentage of cement replaced by red mudes in the concrete increased, the leachability of heavy metals also increased. Nevertheless, the values of the leachability of the concrete specimens were similar for all replacement percentages at both curing times. As seen in Fig. 4, according to the 28-day cure results, the concrete samples that were produced with mixtures of up to $20 \%$ red mud satisfied the $30 \mathrm{MPa}$ strength requirement prescribed for $\mathrm{C} 25$ class concrete. This replacement percentage is also the proper percentage to use according to the heavy metal values.

It can also be seen that the values of $\mathrm{Ca}, \mathrm{K}, \mathrm{Na}, \mathrm{Al}, \mathrm{Fe}$ and $\mathrm{Si}$ measured in the concrete specimens were similar to the values in the corresponding red mud samples.

Water microorganism growth test: The test (according to British Standards BS 6920) assesses the ability of a product to promote a significant degree of growth of aerobic microorganisms when they come into contact with water. This test takes 8 weeks to complete. As seen in Table-9, the difference in the amount of dissolved oxygen at the beginning and the end of the experiment was less than $2.4 \mathrm{mg} / \mathrm{l}$ (Table-10) for all percentages on both curing days. These results indicate that no microbiologic reproduction occurs in the medium for any of the percentages. The results indicate that the aforementioned mixtures containing red mud as an additive material did not experience any issues associated with microorganism reproduction.

\begin{tabular}{ccccc}
\multicolumn{5}{c}{ TABLE-9 } \\
\multicolumn{5}{c}{ DISSOLVED OXYGEN VALUES IN WATER SAMPLES } \\
\hline Sample & $\begin{array}{c}\text { Dissolved } \mathrm{O}_{2} \\
\text { (start, mg/L) }\end{array}$ & $\begin{array}{c}\text { Dissolved } \mathrm{O}_{2} \\
(\text { end, } \mathrm{mg} / \mathrm{L})\end{array}$ & $\begin{array}{c}\text { Difference } \\
(\mathrm{mg} / \mathrm{L})\end{array}$ & Action \\
\hline RM 5 & 7.4 & 6.2 & 1.2 & Pass \\
RM 10 & 7.4 & 6.6 & 0.8 & Pass \\
RM 15 & 7.4 & 6.9 & 0.5 & Pass \\
RM 20 & 7.4 & 6.6 & 0.8 & Pass \\
RM 25 & 7.4 & 6.7 & 0.7 & Pass \\
RM 30 & 7.4 & 6.9 & 0.5 & Pass \\
RM 40 & 7.4 & 6.5 & 0.9 & Pass \\
RM 50 & 7.4 & 6.6 & 0.8 & Pass \\
\hline
\end{tabular}

TABLE-8

METAL CONCENTRATIONS IN THE US EPA TCLP (1311) LEACHATE AT 7 AND 28 DAYS

\begin{tabular}{|c|c|c|c|c|c|c|c|c|c|c|}
\hline & & \multicolumn{9}{|c|}{ TCLP (mg/L) } \\
\hline & & $\mathrm{Cd}$ & $\mathrm{Cr}$ & $\mathrm{Cu}$ & $\mathrm{Ni}$ & $\mathrm{Zn}$ & $\mathrm{Al}$ & $\mathrm{Fe}$ & $\mathrm{Mg}$ & $\mathrm{Si}$ \\
\hline \multicolumn{2}{|c|}{ RED MUD (RM) } & $<0.06$ & 1.8076 & $<0.6$ & 3.3595 & 3.5335 & 390.782 & 61.5923 & 1210.44 & 1234.67 \\
\hline RM 0 & 28 & $<0.06$ & 0.4706 & $<0.6$ & $<0.02$ & 2.9582 & 16.2493 & 3.6852 & 146.300 & 46.0539 \\
\hline \multirow[t]{2}{*}{ RM 5} & 7 & $<0.06$ & 0.5422 & $<0.6$ & $<0.02$ & 1.0925 & 92.1864 & 1693.05 & 182.364 & 832.899 \\
\hline & 28 & $<0.06$ & 0.5470 & $<0.6$ & $<0.02$ & $<0.6$ & 95.8173 & 2255.32 & 190.259 & 603.448 \\
\hline RM 10 & 28 & $<0.06$ & 0.5607 & $<0.6$ & $<0.02$ & $<0.6$ & 108.230 & 1960.18 & 156.845 & 676.349 \\
\hline \multirow[t]{2}{*}{ RM 15} & 7 & $<0.06$ & 0.5062 & $<0.6$ & $<0.02$ & $<0.6$ & 73.2932 & 1260.41 & 143.881 & 635.045 \\
\hline & 28 & $<0.06$ & 0.3209 & $<0.6$ & $<0.02$ & $<0.6$ & 63.3489 & 1258.30 & 163.159 & 304.772 \\
\hline \multirow[t]{2}{*}{ RM 20} & 7 & $<0.06$ & 0.6981 & $<0.6$ & $<0.02$ & $<0.6$ & 144.341 & 2061.10 & 137.085 & 1264.10 \\
\hline & 28 & $<0.06$ & 0.4357 & $<0.6$ & $<0.02$ & $<0.6$ & 67.2728 & 875.267 & 173.386 & 383.925 \\
\hline RM 25 & 7 & $<0.06$ & 0.7093 & $<0.6$ & $<0.02$ & $<0.6$ & 170.562 & 2195.67 & 195.501 & 1300.99 \\
\hline \multirow[t]{2}{*}{ RM 30} & 7 & $<0.06$ & 0.4022 & $<0.6$ & $<0.02$ & $<0.6$ & 95.8681 & 25.7727 & 116.289 & 497.905 \\
\hline & 28 & $<0.06$ & 0.4310 & $<0.6$ & $<0.02$ & $<0.6$ & 68.1729 & 953.712 & 117.595 & 350.897 \\
\hline \multirow[t]{2}{*}{ RM 40} & 7 & $<0.06$ & 0.6862 & $<0.6$ & $<0.02$ & $<0.6$ & 138.617 & 1432.15 & 196.308 & 847.097 \\
\hline & 28 & $<0.06$ & 0.5705 & $<0.6$ & $<0.02$ & $<0.6$ & 74.6566 & 741.007 & 197.779 & 351.219 \\
\hline \multirow[t]{2}{*}{ RM 50} & 7 & $<0.06$ & 0.1068 & $<0.6$ & $<0.02$ & 1.6506 & 120.170 & 18.7678 & 66.8573 & 585.010 \\
\hline & 28 & $<0.06$ & 0.6478 & $<0.6$ & $<0.02$ & $<0.6$ & 89.8093 & 602.542 & 271.668 & 352.837 \\
\hline
\end{tabular}




\begin{tabular}{ccc}
\hline \multicolumn{3}{c}{ TABLE-10 } \\
GROWTH OF AQUATIC MICROORGANISMS \\
TEST REQUIREMENTS (BS 6920) \\
\hline Result $\left(\mathrm{mg} \mathrm{l}^{-1}\right)$ & $<2.4$ & $\geq 2.4$ \\
\hline Action & Pass & Fail \\
\hline
\end{tabular}

\section{Conclusion}

The results of this study that investigated the recycling of red mud via solidification/stabilization methods can be summarized as follows:

- Increasing the percentage of red mud linearly reduced the strength of the concrete specimens because of the high organic content of the red mud.

- The strength increased with curing time.

- Concrete specimens produced with red mud replacing up to $20 \%$ of the cement had compressive strength levels near the $30 \mathrm{MPa}$ value prescribed for $\mathrm{C} 25$-class concrete.

- The leaching concentrations of metals in the manufactured concrete samples were compared with the red mud samples themselves and it was concluded that the solidification/stabilization process was a successful method for recycling red mud.

- The concrete samples that were produced with mixtures of up to $20 \%$ red mud satisfied the $30 \mathrm{MPa}$ strength requirement and this replacement percentage is the proper percentage to use, according to the heavy metal leaching results. The analysis carried out to determine the effects of the produced concrete samples on the water microorganisms revealed that the difference between the starting and ending concentrations of dissolved oxygen was $2.4 \mathrm{mg} / \mathrm{L}$; therefore, there was no organic material dissolution and thus no reproduction of microorganisms.

- Taking into consideration the strength tests and the leaching and water microorganism growth experiments, it was concluded that red mud is suitable as an additive construction product when it is used to replace cement in proportions up to $20 \%$. Red mud used in this way has no hazardous impacts on the environment.

\section{ACKNOWLEDGEMENTS}

This paper was developed under the support of the project TUBITAK, 108Y233. The investigation of the use of building materials with the aim of disposing of different ash and mud samples.

\section{REFERENCES}

1. F. Raupp-Pereira, D. Hotza, A.M. Segadães and J.A. Labrincha, Ceram. Int., 32, 173 (2006)

2. I.M.C. Lo, C.I. Tang, X.D. Li and C.S. Poon, Environ. Sci. Technol., 34, 5038 (2000).

3. D.L. Cocke, M.Y. Mollah, J.R. Parga, T.R. Hess and J.D. Ortego, J. Hazard. Mater, 30, 83 (1992).

4. A.E. Daniels, J.R. Kominsky and P.J. Clark, J. Hazard. Mater, B, 87, 117 (2001).

5. B. Batchelor, Waste Manage., 26, 689 (2006).

6. J.R. Conner, Chemical Fixation and Solidification of Hazardous Wastes, Van Nostrand Reihold, New York, (1990).

7. X.C. Qiao, C.S. Poon and C.R. Cheeseman, J. Hazard. Mater, 139, 238 (2007).

8. C.J. Shi and A. Fernandez-Jimenez, J. Hazard. Mater. B, 137, 1656 (2006).

9. Y.J. Liu, R. Naidu and H. Ming, Geoderma, 163, 1 (2011).

10. R.A. Hind, S.K. Bhargava and S.C. Grocott, Colloid. Surf. A, 146, 359 (1999).

11. M.J. Matteson and L. Orr, Filtration: Principles and Practices, Marcel Dekker Inc., New York, edn. 2 (1987).

12. S. Chandra, Waste Materials Used in Concrete Manufacturing, Noyes Publications, New Jersey, (1996).

13. L. Senff, D. Hotza and J.A. Labrincha, Construct. Build. Mater, 25 163 (2011).

14. L.G. Mason, Focus on Hazardous Materials Research. New York: Nova Science Publishers Inc., (2007).

15. A.T. Hubbard, Encyclopedia of Surface and Colloid Science. New York: Marcel Dekker Inc., (2002).

16. J.E. Kogel, in eds: K.J. Elzea, C.T. Nikhil and M.B. James, Industrial Minerals and Rocks: Commodities, Markets and Uses, US, edn. 7 (2006).

17. P. Somasundaran, Encyclopedia of Surface and Colloid Science, New York: Taylor \& Francis Group, edn. 2 (2006).

18. J. Yang and B. Xiao, Const. Build. Mater, 22, 2299 (2008).

19. M. Singh, S.N. Upadhayay and P.M. Prasad, Waste Manage, 16, 665 (1996).

20. M. Singh, S.N. Upadhayay and P.M. Prasad, Cem. Conc. Res., 27, 1037 (1997).

21. P.E. Tsakiridis, S. Agatzini-Leonardou and P. Oustadakis, J. Hazard. Mater., 116, 103 (2004).

22. I. Vangelatos, G.N. Angelopoulos and D. Boufounos, J. Hazard. Mater., 168, 473 (2009).

23. J. Pera, R. Boumaza and J. Ambroise, Cem. Conc. Res., 27, 1513 (1997).

24. P. Zhihua, L. Dongxu, Y. Jian and Y. Nanru, Cem. Conc. Res., 33, 1437 (2003).

25. P. Zhihua, Z. Yanna and X. Zhongzi, J. Wuhan. Univ. Technol.-Mater, 24, 161 (2009).

26. K. Kohno, A. Sugimoto and T. Kashiwai, The Effects of Finely Ground Silica, Silicafume and Red Mud on Alkali-Silica Reaction and Compressive Strength. Alkali-Aggregate Reaction. In: 8th International Conference, Taylor and Francis (1989).

27. J. Somlai, V. Jobbágy, J. Kovács, S. Tarján and T. Kovács, J. Hazard. Mater, 150, 541 (2008). 